CHAPTER I 3

\title{
Virtue, self-mastery, and the autocracy of practical reason
}

Anne Margaret Baxley

Kant's theory of virtue has received considerably less attention than the moral theory set out in his most widely read ethical texts, the Groundwork of the Metaphysics of Morals and the Critique of Practical Reason. Moreover, this account of virtue has not always been well understood. In light of the fact that Kant characterizes virtue in terms of strength of will over feelings and inclinations that conflict with duty, commentators have suggested that Kant's account of virtue is impoverished, insofar as it appears to be a recipe for nothing more than continence. ${ }^{\mathrm{I}}$ Part of the problem in uncovering a comprehensive picture of Kant's full account of moral character lies with Kant, for his remarks about virtue in his later and less well-known writings are scattered and not always systematically presented. Although the Doctrine of Virtue contains a sustained treatment of virtue and our various ethical obligations (duties of virtue), that work requires careful interpretation and reconstruction. Fortunately, Kant's Lectures on Ethics, now easily accessible in English translation, provide an additional valuable resource for readers interested in understanding a more complete picture of Kant's conception of virtue, its importance in his overall ethics, and its relation to other foundational concepts in his moral theory.

This essay analyzes four central theses concerning the nature of virtue that Kant himself emphasizes in the Lectures on Ethics. Although these four themes do not provide an exhaustive account of Kant's theory of virtue, together they lay a solid foundation for any systematic interpretation of Kant's considered views on moral character.

\footnotetext{
I This distinction between full virtue and mere continence, which is crucial for Aristotle's moral psychology, is understood to be a distinguishing feature of classical virtue ethics more generally. Contemporary theorists who have questioned whether Kant has the resources to distinguish between the person who merely acts rightly and the person who is wholehearted in what she does include Julia Annas, Talbot Brewer, David Brink, Rosalind Hursthouse, and Martha Nussbaum. See Annas 1993, 53 and 2006, 517; Brewer 2002; Brink 1999, 580 and 2000, 431; Hursthouse 1999, 104; and Nussbaum 200I, I72. I explore this theme at length in Baxley 2010.
} 


\section{Virtue involves moral self-mastery and moral strength of will}

In the Lectures on Ethics, Kant appeals to the key notion of self-command or self-mastery (Selbstbeherrschung) to characterize virtue. Self-control in the service of prudence, which ultimately aims at the satisfaction of inclination, is not sufficient for virtue, for, as Kant puts it, "true self-control is moral in character" (C 27:36I). The self-control crucial for moral agency is distinguished from mere prudential self-control in that it involves mastering and ruling the rabble of sensibility so that one possesses the fortitude to do one's duty from duty in spite of any obstacles that might stand in the way (C 27:360-362). Virtue, as Kant thus conceives of it, primarily involves power, strength and authority $\left(\mathrm{C}_{27} 7465 ; \mathrm{V} 27: 492\right)$. More specifically, it is a distinctly moral strength of will or soul, where strength connotes the force to withstand all temptations to transgress the moral law and is manifest in a victory over inclination (C 27: 465; M II 29:603-606; V 27:49If). ${ }^{2}$

In his discussions of virtue, Kant draws a distinction between an executive and a directing power of the will, indicating that self-mastery is distinguished not only from mere prudential self-regulation, but also from the more familiar Kantian conception of self-legislation. In his words: "We have a double authority over ourselves, the disciplinary and the productive. The executive authority can compel us, in spite of all impediments, to produce certain effects, and in that case it has might. But the directing authority exists merely to guide the forces of the mind" (C 27:363). The notion of a disciplinary or executive authority that Kant invokes here in an effort to highlight what is characteristic of self-mastery is described as an acquired strength of will to compel ourselves to act in accordance with norms of pure practical reason (norms that we give ourselves in virtue of our directing authority). The thought behind this distinction is that, as self-legislating beings with autonomous wills, we are capable of directing ourselves to comply with moral laws grounded in pure practical reason alone. More than this legislative authority is required of us, however, if we are to live fully in accord with the demands of pure practical reason, executing the moral law. For this task, we need selfmastery, the actual moral strength of will to weaken a strong (internal) opponent to duty and to put the law into practice. In underscoring the idea that such rational self-command is the very condition under which we finite rational beings have the power to resist being determined to act by

2 For Kant's account of virtue as moral strength of will in the Metaphysics of Morals, see MS 6:389, 393, 397,405 , and $408 f$. 
strong natural inclinations and to conform our wills to self-legislated moral commands, Kant explains:

That man, moreover, should act in accordance or adequacy with the moral laws, can occur insofar as he has repressed and conquered, through the moral law, the inclination he harbors to deviate or do the opposite. The struggle of inclination with the moral law, and the constant disposition (intentio constans) to carry out his duties, therefore constitutes what we call virtue. (V 27:492)

It should come as no surprise that being one's own master in this Kantian sense requires self-discipline and self-compulsion (Selbstzwang) (M II 29:6I6-6I8; V 27:520f). In disciplining herself, the virtuous agent plays the role of sovereign over herself, or, better, is one in whom morality itself has sovereign authority (C 27:36I). In light of the fact that passions, as Kant conceives of them, are pernicious forms of inclination that conflict with moral concerns and lead readily to vice, moral self-discipline involves ruling oneself so that one has no passions. ${ }^{3}$ In short, morality commands us to yield nothing to passion, a point that leads Kant to praise the Stoics for recommending the extirpation of passions as the proper path to virtue (C 27:368). ${ }^{4}$

Of course, the notion of self-compulsion might sound like a harsh or repressive recommendation for acquiring moral character. Kant, however, believes that self-discipline carries with it its own rewards. As a form of strength, virtue comes in degrees, and the more disciplined and hence virtuous a person is, the more he is free $\left(\mathrm{V}\right.$ 27:520). ${ }^{5}$ In emphasizing this close connection between virtue, self-compulsion, and freedom, Kant insists:

The more a man considers a moral act to be irresistible, and the more he is compelled to do it by duty, the freer he is. For in that case he is employing the power he has, to rule over his strong inclinations. So freedom is all the more displayed, the greater the moral compulsion. (M II 29:6I7)

\footnotetext{
${ }^{3}$ Kant holds that affects (Affekte) and passions (Leidenshaften) are particular forms of feelings and inclinations that are inherently problematic from the standpoint of both morality and prudence, because they are directly contrary to reason. For Kant's remarks about affects and passions in relation to virtue and self-mastery in the Lectures on Ethics, see C 27:368 and V 27:612. Kant's official account of affects and passions in his published writings can be found in MS 6:407-409; ApH 7:25I-282; KU 5:272n.; and RGV 6:29n. For a helpful discussion of the connection between Kant's views regarding affects and passions and the Stoics, see Sherman 1997, I2I-I86. Julia Annas' analysis of the Stoics' account of emotions also includes a useful comparison of the Stoics and Kant. See Annas 1993, 53-66.

4 Although Kant shares the Stoic view that passions are wholly at odds with reason and must be avoided, he expresses doubts about how far we can progress in getting rid of them (C 27: 368).

5 For an excellent discussion of Kant's conception of virtue as a source of inner freedom, see Engstrom 2002.
} 
Moreover, the self-commanding agent enjoys a sense of equanimity that stems from the fact that he does not experience strong inner turmoil between duty and contrary inclinations. ${ }^{6}$ The state of the soul of the agent lacking in virtue, by comparison, is characterized in terms of ongoing conflict and strife. As Kant characterizes the difference: "Without disciplining his inclinations, man can attain to nothing, and hence in self-mastery there lies an immediate worth, for to be master over oneself demonstrates an independence of all things. Where there is no such self-mastery there is anarchy" (C 27:36If). Still worse, the vicious person is portrayed as being enslaved by the power of natural inclinations (C 27:464). In light of the fact that moral self-discipline and self-mastery promotes freedom from determination by strong inclinations and signifies a condition of the soul akin to psychic harmony (a sense of inner freedom), it is easy to see why Kant holds that virtue is its own reward. ${ }^{7}$

\section{Autocracy is the ideal form of moral self-governance required for virtue}

Kant's various comments concerning the nature of virtue and selfcommand in the Lectures on Ethics indicate that he belongs to a rich philosophical tradition of theorizing about virtue that relies heavily on political metaphors about governance to illuminate moral ideals about self-governance. We are told that the self-mastery required for virtue provides a model for a "vigilant government," one in which reason must exercise force in relation to sensibility in order to "compel this rabble under the rule in accordance with ordinance and regulation" (C 27:360). The specific term Kant uses to characterize his favored ideal form of moral selfgovernance is autocracy. Although he explicitly appeals to the term only once in his most extended published treatment of virtue, the Doctrine of Virtue, it appears or is suggested more frequently in his remarks about virtue and self-mastery in the Lectures on Ethics. This notion of autocracy underlies

\footnotetext{
${ }^{6}$ In the Critique of Practical Reason, Kant claims that virtues involves consciousness of mastery over inclinations and produces a sense of independence from inclinations, thereby affecting a feeling of moral contentment that Kant describes as a negative form of happiness ( $\mathrm{KpV}$ 5:II8f). For other passages in which he elaborates on the relation between virtue, self-compulsion, freedom, and moral contentment, see M II 29:617; V 27:520, 643, 647f; KpV 5:38, III-II9, I55f, I6I; and MS 6:380, $406 f$. 7 Kant repeatedly warns against recommending virtue for its beneficial consequences, insisting that virtue should be praised because it possesses its own inner worth and is its own reward. For Kant's account of virtue as its own reward, see G 4:426n., 442f, 450; and MS 6:391, 396, 406.
} 
Kant's considered account of moral character, providing the key to understanding his distinctive concept of virtue. ${ }^{8}$

Kant introduces the notion of autocracy by insisting that true moral strength of will involves autocracy in addition to autonomy, noting that, "[i]f reason determines the will through the moral law, it has the force of an incentive, and in that case has, not autonomy merely, but also autocracy. It then has both legislative and executive power" (M II 29:626). Autocracy signifies the self-command at the heart of virtue, for it represents "the authority to compel the mind, despite all the impediments to doing so. It involves mastery over oneself, and not merely the power to direct" (C 27:362). As actual strength of will to resist forces in conflict with duty, autocracy is consistently portrayed as an executive authority or power of the will, which Kant contrasts with a separate legislative authority or power to guide the will in accordance with norms of pure practical reason ( $\mathrm{C}$ 27:362; M II 29:626). Kant speaks of an autocracy of "the moral law" (or "laws"), "reason," or "freedom," but also refers to an autocracy of the "soul," "heart" or "mind" over inclinations. ${ }^{9}$ When he appeals to the concept of autocracy in the Doctrine of Virtue, he uses it in precisely the same way as in the Lectures on Ethics, namely, to underscore its importance for his overall picture of virtue as acquired moral strength of will and to distinguish it from autonomy. Having differentiated between a doctrine of morals, which he explicitly connects with autonomy, and a doctrine of virtue, which he says "also" involves autocracy, Kant explains that autocracy is distinct from autonomy insofar as it involves "consciousness of the capacity to master one's inclinations when they rebel against the law, a capacity which, though not directly perceived, is yet rightly inferred from the moral categorical imperative" (MS 6:383, 515). ${ }^{\text {IO }}$

Kant understands autocracy foremost as a form of self-rule in accordance with the commands of practical reason over sensibility, a model of selfgovernance presupposing the power to control and limit the influence on the will of feelings and inclinations at odds with moral demands. It stands

${ }^{8}$ For my extended treatment of Kant's account of autocracy, see Baxley 2oIo. In addition, see König 1994. For a nice discussion of the intrinsic value of autocracy in Kant's ethics, see Guyer 1993, 346-350 as well as Guyer's later discussion in Guyer 2005, 136-I4I. Other brief accounts of autocracy can be found in Allison 1990, I64 and Carnois 1987, I20.

9 Kant refers to an autocracy of practical reason (MS 6:383) or reason (M II 29:626), an autocracy of moral laws (VMS 23: 396), and an autocracy of freedom in relation to happiness ( $\#$ \#6867, 19:186). For passages focusing on autocracy as a power of the heart, soul, or mind, see $\mathrm{C} 27: 362,364,368,378$.

Io Similarly, in his notes to the Doctrine of Virtue, he writes that the virtuous person is conscious of "an autocracy (not merely autonomy) of moral laws against all conflicting impulses of sensibility (inclinations)" (VMS 23:396). 
for the executive power of the soul to enforce the morally good choices legislated by the directing or guiding power of the will (a power belonging to the rational will in virtue of the property of autonomy) (M II 29:626). The fact that autocracy represents the executive authority of reason's prescriptions in accordance with moral laws underlies Kant's repeated remark that autocracy is the subjective condition of the performance of duty, for, as he puts it, maintaining command over oneself is the condition under which one is able to perform the self-regarding duties and thereby all other duties (C 27:360, 364, 368).

Although Kant tends to identify autocracy with rational rule over sensibility, it is important to note that he conceives of autocracy as a broad and encompassing form of moral self-governance, one that is not exhausted by the simple notion of strength in opposition to sensible feelings and inclinations. Kant holds that human beings possess various mental powers that bear on morality, and he explicitly discusses the ways in which autocracy shapes and transforms these morally relevant powers in the virtuous agent (C 27:364-368). For instance, the autocratic agent is skilled in controlling her imagination, so that her imagination does not tempt her to pursue objects that are beyond her reach or especially hard to attain. She is able to suspend judgment on important matters and is thereby able to refrain from making rash decisions or acting prior to rational reflection. She possesses what Kant calls the "power of presence of mind," characterized as a harmony of one's mental powers, where such harmony eases the burden of carrying out one's work (C 27:366). In addition, the autocratic agent demonstrates a degree of self-knowledge and capacity for self-examination that the weak-willed agent and the vicious agent lack. By disciplining herself, instead of yielding to emotions and inclinations, the autocratic agent has the fortitude to resist feelings and inclinations that can pose temptations to duty; she displays constancy of mind and the cheerful heart of virtue; and she enjoys a feeling of inner worth that is consequential upon having a firm disposition to do one's duty from duty (C 27:36If; M II 29:617, 623; V 27:520, 643, 648f).

Given Kant's more familiar concept of autonomy, the question naturally arises: What is the precise relation between autonomy and autocracy? This interpretive puzzle is best addressed by recalling the main features of Kant's critical view (first laid out in the Groundwork of the Metaphysics of Morals) that autonomy is a property of the rational will and the foundational principle of morality. In the Groundwork, Kant defines autonomy as "the property of the will by which it is a law to itself (independently of any property of the objects of volition)" (G 4:440). Autonomy, so conceived, 
is essentially a capacity for self-legislation, a capacity implying the freedom to make universal law through one's own will, or freedom to adopt maxims of action that are valid for oneself only insofar they are valid for all other rational agents. According to Kant's particular conception of autonomy, the laws that we give ourselves are prescriptions of our own reason, through which we freely constrain ourselves in light of our recognition of their validity for all rational agents.

On the regressive, analytic method of argument he employs in the Groundwork, Kant assumes that morality requires acting on the basis of the categorical imperative. He then introduces autonomy as the supreme principle of morality in the sense of being the necessary condition of the very possibility of morality. The key point to Kant's argument in the Groundwork is that acting on the basis of the categorical imperative presupposes a capacity to determine oneself to act independently of, and even contrary to, one's particular interests as a sensuous being with needs, namely, one's empirical interests. Kant treats this notion of selfdetermination as one that is built into the characterization of autonomy as a property of the will. That is, a will and only a will with the property of autonomy is capable of acting on the categorical imperative, because only a will capable of determining itself independently of its needs as a sensuous being can act in accordance with a practical principle that commands unconditionally because of its mere form. ${ }^{\text {II }}$

This reminder of how Kant conceives of autonomy indicates that the relation between autonomy and autocracy can be captured by distinguishing between a legislative authority or power of the will for creating and giving to oneself laws that are universally valid and an executive authority or power of the will for enforcing and enacting these laws. The former capacity for selfdetermination by pure practical reason is one that we all possess in virtue of our autonomy, and it defines our moral personality. The latter power of selfrule by pure practical reason is one that we can acquire through a process of moral self-discipline and self-mastery, and it describes our empirically acquired moral character.

One final point regarding the nature of autocracy is worth mentioning. In spite of the unfortunate political connotations associated with the term, in the Lectures on Ethics, Kant denies that autocracy amounts to wholesale self-repression. Whereas Baumgarten endorses the idea that virtue entails self-overcoming or self-conquest (Selbstüberwindung) in Philosophical Ethics (one of the two texts Kant regularly included for discussion in his course on

\footnotetext{
II My understanding of Kant's conception of autonomy is indebted to Allison 1990, 85-106.
} 
ethics), Kant rejects the idea that proper self-governance by reason involves waging a war against oneself. As he explains:

Our author goes on to speak of self-conquest. But if a man rules himself so well that he prevents any rebellion of the rabble in his soul and keeps peace within it (which here, however, is not contentment with everything, but good command and unity within the soul), and if he now conducts so good a government within himself, then no war will arise in him, and where there is no war, no conquest is necessary either. It is therefore far better if a man is so governed that he need gain no victory over himself. (C 27:368f)

In short, although autocracy represents a form of self-governance in which practical reason is sovereign, Kant imagines autocracy to be distinct from both anarchy (where the mob of sensibility rules over reason) as well as tyranny (where reason exercises excessive force over sensibility). Kant explicitly cautions us not to go too far in disciplining our natural inclinations. He thinks excessive self-discipline is actually opposed to our duties to self, for we have an obligation to provide for ourselves so that we find satisfaction in life (MS 6:452). It is this very thought - that morality does not require self-denial - that leads Kant to criticize Diogenes for taking things too far and overdoing the duty to do without (V 27:650). ${ }^{\text {I2 }}$ Accordingly, Kant rejects the view he labels ethica morosa (killjoy ethic) on the grounds that is involves the sacrifice of "all wished-for enjoyment of happiness" (V 27:663). The Kantian autocratic agent, in whom reason reigns supreme, need not conquer herself, but must merely work to maintain constant vigilance over her inclinations so that she knows how to determine herself to act on moral principles in good or ill fortune (V 27:663).

\section{Virtue presupposes conflict and struggle and is thereby distinct from holiness}

In analyzing the strength required for moral character, Kant regularly contrasts virtue and holiness, largely to underscore the fact that virtue presupposes some element of conflict and struggle. Holiness signifies complete purity of will, even of thought. It represents a state of mind from which an evil desire never arises (M II 29:604). In light of the fact that a holy

${ }^{12}$ Diogenes allegedly lived in a wine jar, possessed only one cloak, and discarded his cup so that he could drink out of his hands, all in the name of simplicity. From Kant's perspective, however, Diogenes' life exemplifies the kind of "morose" or "monkish" virtue we should reject, for there is no purpose in punishing ourselves by denying ourselves what we can easily acquire (C 27:393f). 
will possesses a pure moral disposition innately and consequently wills only what the moral law prescribes, a holy will has no need for virtue, as "the strength of the resolve to perform our duties, and to strive against the constant enticements to do otherwise which sensory feelings inspire" (V 27:570). ${ }^{13}$ Virtue is thus relevant only for finite (sensuous) rational beings, imperfect beings who have needs and inclinations that can conflict with duty and who must exercise self-constraint in order to do what the law commands (M II 29: 605f). In emphasizing the notion that virtue entails the real possibility of acting contrary to the moral law and is thus limited in scope to finite creatures in whom there are genuine obstacles to morally good conduct, Kant explains:

Ethics explained by a doctrine of virtue is good inasmuch as virtue belongs solely before the inner tribunal; but since virtue entails, not just morally good actions, but at the same time a great possibility of the opposite, and thus incorporates an inner struggle, this is therefore too narrow a concept, since we can also ascribe ethics, but not virtue (properly speaking) to the angels and to God; for in them there is assuredly holiness but not virtue. $(\mathrm{H} 27: 13)$

Readers of Kant's ethics will recall that at times Kant portrays inclinations themselves as the fundamental problem with which we must contend in our efforts to fulfill our moral obligations and live in conformity with the moral law. Inclinations are alleged to be blind and servile and always burdensome to a rational being (KpV 5:II8). In both the second Critique and the Groundwork, Kant insists that inclinations are so problematic that it must be the universal wish of all rational beings to be completely free of them (KpV 5:II8; G 4:428). The thought that inclinations are the main impediment to the conformity of the finite rational will moral laws is likewise implied in passages from the Lectures on Ethics in which Kant warns that virtue requires constant vigilance over inclinations and is manifest in a victory over them (V 27:663; C 27:465). ${ }^{\mathrm{I}}{ }^{\mathrm{T}}$ Yet, the true opponent of virtue, as Kant sees it, lies much deeper than our inclinations, namely, in an actual tendency to evil on our part, which Kant understands as a tendency we have to subordinate duty to inclination, thereby granting priority to

${ }^{13}$ For passages in the Lectures on Ethics in which Kant contrasts virtue and holiness, see $\mathrm{H}$ 27:13; C 27:463f; M II 29:604-606, 6II; and V 27:486-492, 518-520. In the Critique of Practical Reason, Kant defines virtue as a "moral disposition in conflict (im Kampfe), and not holiness in the supposed possession of a complete purity of dispositions of the will" ( $\mathrm{KpV} 5: 84)$. For additional passages in his published writings in which he distinguishes virtue from holiness, see $\mathrm{G} \mathrm{4} 4439$; $\mathrm{KpV}$ 5:32f, I22, I28; and MS 6:383, 396f, 405 .

${ }^{14}$ Similarly, in the Doctrine of Virtue, Kant characterizes virtue as an acquired capacity "to overcome all opposing sensible impulses" (MS 6:397). 
considerations based on our happiness over moral concerns. Virtue is "the strength of soul to withstand, out of duty, the onset of evil," or "an aptitude, on moral principles, for overcoming the inclination to evil" (M II 29:603; C 27:463). In the Lectures on Ethics, Kant characterizes this inclination to evil as an inclination to deviate from the moral law and act in opposition to it $(\mathrm{V}$ 27:492). In a notable passage in which he makes explicit the idea that the internal struggle we face in our efforts to conform our actions to the law is not one of merely controlling our inclinations, but overcoming a deepseated tendency to transgress the moral law, Kant claims:

It is just because he possesses by nature a nevertheless conquerable tendency and propensity to evil, so that he harbors the possibility of being easily drawn away from good intro transgression, that duty is coupled, in his case, with moral necessitation, and the latter needed for virtue. (V 27:57I)

In Religion within the Boundaries of Mere Reason, Kant labels this tendency to evil "radical evil" in the context of arguing for his official doctrine that there is a universal, freely chosen propensity (Hang) to evil in human nature. ${ }^{15}$ In calling evil "radical," Kant does not mean to imply that humanity is diabolically evil. Instead, he explicitly states that the term "radical" should be understood in its etymological sense of "roots." ${ }^{\text {I6 }}$ Radical evil for Kant thus signifies the very ground (or root) of the possibility of moral evil in general and of all actions that are contrary to duty (RGV 6:32).

In Religion, Kant expounds on this doctrine of radical evil by noting, "the statement, 'The human being is evil,' cannot mean anything else than that he is conscious of the moral law and yet has incorporated into his maxim the (occasional) deviation from it" (RGV 6:32). In other words, the claim that there is universal propensity to evil in human nature amounts to the claim that we have a tendency to exercise our free choice (Willkür) by adopting a fundamental maxim to subordinate the moral law to non-moral considerations based on happiness and its principle of self-love (RGV 6:36). Simply put, Kant holds that we human beings have a propensity to treat happiness as our supreme or unconditioned good, or a tendency to act in accordance with the dictates of morality only on the condition that what morality

Is Kant explicitly introduces the doctrine of radical evil in Religion (I793), but the outlines of this doctrine can be found earlier, in the Groundwork (1785), where Kant writes of "a natural dialectic" of practical reason, understood as a "propensity to rationalize against those strict laws of duty and to cast doubt upon their validity, or at least upon their purity and strictness, and, where possible, to make them better suited to our wishes and inclinations, that is, to corrupt them at their basis and to destroy all their dignity" (G 4:405; cf. G 4:424).

${ }^{16}$ The Latin radic- means "roots." Kant explains that the kind of evil he has in mind is one that is "entertwined [verwebt] with humanity itself and, as it were, rooted [gewurzelt] in it" (RGV 6:32). 
requires of us does not conflict with the satisfaction of our inclinations (the sum total of which is happiness).

Of course, the thesis humanity is evil in this sense is a substantive thesis about human nature, one that sharply separates Kant from classical virtue theorists. In a discussion in the Lectures on Ethics in which he raises this very point, Kant indicates that the various ideals of human excellence found in antiquity fail to provide an appropriate measure of human virtue, precisely for the reason that the ancients did not see that finite imperfect beings always require moral strength of will in the face of a powerful (internal) opponent to duty in the struggle to lead morally good lives. From this Kantian perspective, then, Diogenes' perfect man of nature, who lives fully in accordance with reason without struggle, "has no need of virtue, for he has no concept of evil" (M II 29:603). In short, as Kant sees it, a concept of virtue fitting for us mere human beings must retain some element of what the ancients would view as continence - strength of will in the face of opposition to duty - because virtue itself is a corrective (more specifically, a corrective to a strong tendency we have to grant priority to inclinations over the moral law). ${ }^{17}$ As Kant thus warns us in the context of reacting to these ancient models of human excellence: "We can attain to virtue, i. e. a moral preparedness to withstand all temptations to evil, so far as they arise from inclinations. The ancient philosophers never got to that point" (M II 29:604).

The key idea that the very concept of virtue presupposes a notion of inner conflict does not imply that the Kantian virtuous agent constantly struggles with actual contrary-to-duty inclinations, always doing her duty from duty in the face of temptation, or that Kant simply indentifies virtue with mere continence. On the contrary, the self-commanding agent who has acquired the moral strength of will to govern her sensible nature and successfully hold in check her tendency to evil does not experience the internal turmoil that the continent person and the weak-willed person feel. The Kantian autocratic rules herself in accordance with practical reason and plays the master over herself; as a result, she possesses a form of independence from inclinations and the temptations associated with them. If we recall, the reason Kant rejects the idea that virtue involves winning a battle over oneself (selfconquest) is that autocracy signifies a soul that is unified and at peace,

\footnotetext{
17 In the Lectures on Ethics, Kant focuses primarily on four particular classical ideals of human excellence: the Cynic ideal of Diogenes and Antisthenes (natural simplicity), the Epicurean ideal (the man of the world), the Stoic ideal of Zeno (the sage), and the Christian ideal of holiness (M II 29:603-605; $\mathrm{V} \mathrm{27:647-650).} \mathrm{In} \mathrm{each} \mathrm{case,} \mathrm{Kant} \mathrm{thinks} \mathrm{these} \mathrm{ideals} \mathrm{miss} \mathrm{something} \mathrm{at} \mathrm{the} \mathrm{very} \mathrm{heart} \mathrm{of} \mathrm{virtue,}$ insofar as virtue involves strength in overcoming a serious "hindrance in the will" (a tendency to evil).
} 
and not in a perpetual state of discord (C 27:368f). Still, the point remains that, for Kant, acquiring a virtuous disposition always takes place in a particular context, namely, one in which we must first break with or overcome a deep-seated tendency to give priority to inclination over duty, a tendency we must subsequently remain on guard against, since it can be overcome and repressed and hence not acted on, but never entirely eliminated (C 27:463f). ${ }^{\text {I8 }}$

\section{Virtue amounts to a disposition to do one's duty from duty and therefore entails constraint and necessitation by practical reason}

Should there be any doubt as to whether Kant treats the concept of duty as central in his theory of virtue, it is important to see that Kant conceives of virtue as a settled disposition to do one's duty from duty, or out of respect for the law (C 27:308; M II 29:6II, 624; V 27:623f, 7I5). Virtue has its own motive, which springs from the inner goodness of actions (C 27:308). ${ }^{19}$ For one's action to have moral merit, it is required is that "the action should have arisen from a purely moral intent, or that only the moral law, and not inclination of any kind, should have been the motive for it" (V 27:6II). The thought that a morally good disposition involves strength of resolve to fulfill one's duties from the motive of duty, not inclination, helps explain why virtue does not make us happy. In Kant's words:

Virtue does not flit or curry favor, but is honorable. Duty is not what I do for my advantage, but what I do for the sake of the law. The cast of mind which is won over only by reward, is called indoles servilis; that which acts only for

I8 The fact that virtue presupposes conflict and struggle with a formidable (internal) opponent explains why Kant describes the process of acquiring a virtuous disposition in terms of a radical "change of heart" or "conversion" (RGV 6:47f; C 27:464). Becoming morally good involves reorienting one's way of thinking or cast of mind (Denkungsart), by conquering a tendency to evil and adopting an entirely different fundamental maxim always to subordinate inclination to duty. Moreover, sustaining one's virtuous disposition requires continual effort, for the propensity to evil is a powerful foe that can be overcome but never entirely vanquished. As Kant describes this ongoing ethical task: "However virtuous a man may be, there are tendencies to evil in him, and he must constantly contend against them. He must guard against the moral self-conceit of thinking himself morally good, and having a favorable opinion of himself; that is a dream-like condition, very hard to cure" (C 27:264).

19 In Collins (reflecting notes originally from 1774-I777), where Kant never explicitly formulates the categorical imperative, he stresses the importance of believing that the rational awareness of what is intrinsically right and dutiful can move us to act. At times, however, he seems to doubt whether such rational awareness alone is sufficient for motivation. On this point, see Schneewind 1997a, xvi. Although Kant may waver on this point in Collins, his later discussions in Mrongovius II (I784-I785) and Vigilantius (I793-1794) are decisive that virtue involves acting dutifully from duty. 
the sake of duty, is indoles erecta. That act alone is morally good, which is done because it is a duty. (M II 29:624)

The fact that Kant treats virtue and duty as moral concepts that cannot be prised apart underlies his claim that there is only one (purely) formal principle of ethics or general principle of virtue (one obligation of virtue), namely, the duty to do all of our duties from duty (V 27:54I).

An important consequence of this account of motivation in the virtuous person is that moral obligation involves the necessitation of the will by practical reason. To act from duty is to act from a voluntary feeling of respect for the moral law, where acting from such a rationally grounded feeling necessarily involves self-constraint and moral compulsion, and signifies that we obey the law in the face of opposition from inclinations (M II 29:617; V 27:518-520). Kant reasons that, if morality ceased to involve the necessitation of the will by practical reason, we would no longer experience moral laws as imperatives, or have any need for virtue, as a steadfast disposition to fulfill one's duties strictly:

Where there is no necessitation, there also no moral imperative, no obligation, duty, virtue, ought or constraint is conceivable. Hence the moral laws are called laws of duty, because they presuppose an agent subject to impulses of nature. ( $\mathrm{V}$ 27:489)

It is this key aspect of Kant's account of virtue - that abiding by moral laws from a purely moral disposition involves doing one's duty from duty and a feeling of necessitation by practical reason - that accounts for Kant's fundamental disagreement with Schiller. Readers familiar with Schiller's critique of Kant's rationalist moral theory in "On Grace and Dignity" will recall that Schiller claims to agree with the fundamental tenets of Kant's moral theory. His concern is primarily with the manner in which Kant presents his doctrines. According to Schiller, the problem with Kant's presentation of his moral theory is that it that it leaves us with the harsh impression that inclination is "a very suspicious companion, and pleasure a dangerous auxiliary for moral determinations" (GD I69; 205). ${ }^{20}$ Schiller, however, thinks that this rigid Kantian picture can be improved upon by attempting to "uphold, in the realm of appearance and in the actual practice of moral duty, the claims of sensibility, which are completely repudiated in the realm of pure reason and in moral legislation" (GD I69f; 205). In terms

20 "On Grace and Dignity" was first published in $\mathrm{I} 793$ in the second edition of Neue Thalia. References to this essay (GD) are to Schiller 1966 and to the corresponding page in the anonymous English translation of 1902 . 
of Schiller's governing metaphor, this emphasis on the aesthetic dimension of morality will show how Kantian dignity (Würde) is complemented and perfected by grace $(A n m u t)$.

For our purposes here, the crucial aspect of Schiller's critique to keep in mind is that he thinks virtue requires cultivating one's sensible nature to harmonize positively with reason so that the virtuous person is inclined to act in accordance with the moral law and takes pleasure in moral action. ${ }^{2 \mathrm{I}}$ Schiller conceives of the person who has unified her sensible and rational natures as a "beautiful soul," where a beautiful soul is considered a "child of the house" of practical reason, as opposed to its "servant" (GD I72; 208). In light of the fact that a child of the house has trained her inclinations to accord with duty and to work toward bringing about morally good ends, she is not required to consult reason for guidance before she acts and can even "abandon herself with a certain security to instinct" (GD I73; 209). Schiller argues, further, that this beautiful soul does not experience the moral law as an obligation signifying compulsion and constraint (GD I72; 208). In short, Schiller denies that moral laws necessarily take the form of categorical imperatives for all finite rational beings on the grounds that the imperatival form of the law would strike a child of the house as "a foreign and positive law," a law imposed by an external authority (GD I72; 208). He holds that the person who displays grace is not the one who forces herself to act dutifully, relying on the thought of duty as an incentive, but the one whose inclinations have been so completely transformed as to elicit the right conduct without being commanded, and without experiencing the moral law as an imperative at all.

Kant's published reply to Schiller appears in a famous footnote in Religion (RGV 6:23f n.). Yet, while Kant's reaction to Schiller in Religion is ambiguous, an important discussion in the Vigilantius' lecture notes on ethics is especially instructive in explaining why Kant rejects Schiller's account of the beautiful soul as an exemplar of moral virtue. ${ }^{22}$

${ }^{21}$ Schiller identifies virtue as "nothing other than an inclination for duty," and he insists that, "unless obedience to reason is a source of pleasure, it cannot become an object of inclination" (GD I70, I69; 206, 204).

22 In Religion, Kant states that he and Schiller agree on the most important principles (RGV 6:23n.). Kant then explains that he explicitly distinguishes dignity from grace in an effort to emphasize the purity of duty, which involves "unconditional necessitation, to which gracefulness stands in direct contradiction" (RGV 6:23n.). Nevertheless, Kant says that Schiller's graces are relevant when we turn from an analysis of the nature and ground of moral obligation to consider the aesthetic character of virtue, that is, the feelings associated with virtue as a character trait and the feelings that virtue elicits in us as rational appraisers. In acknowledging that the graces accompany virtue, Kant thus emphasizes the idea that the temperament of the virtuous person is joyous and that the virtuous person does her duty with a cheerful heart. Yet, as commentators have noted, Kant overstates the matter when he 
In Vigilantius, Kant prefaces his discussion of Schiller by explaining that, for a holy will, what is objectively necessary is also subjectively necessary, which means that a holy will does what the moral law requires without having to be commanded. By contrast, for a finite rational will, whatever action the laws of reason command "does not always result from them, owing to its subjective contingency, rooted in the impulses of human nature" (V 27:489). As we have seen, virtue presupposes some element of struggle and (inner) conflict because our very condition is one in which we must overcome a deep-rooted tendency of will to act on sensible feelings, desires, and interests that run contrary to the moral law. This means that we can never get beyond the bare possibility of being tempted to act contrary to duty and hence we require virtue, as an acquired moral strength of will to constrain or compel ourselves (in accordance with duty) to do what we would not do of our own accord (by our very nature). Whereas Schiller thinks that the moral law takes the form of an imperative only insofar as an agent actually has contrary inclinations that pose temptations, for Kant, the imperatival form of the moral laws presupposes only the possibility for transgressing the moral law, not actual temptation.

Furthermore, given that moral imperatives entail a notion of necessitation of the finite will by practical reason, Kant remarks that it is "contrary to the nature of duty to enjoy having duties incumbent upon one" (V 27:489). On the contrary, we obey the law reluctantly, that is, in the face of opposition from a formidable opponent, an opponent that virtue as "a steadfast determination in obeying the moral laws" enables us to overcome (V 27:490). As Kant thus makes clear in his discussion of Schiller, we require a power of self-constraint and moral compulsion in our efforts to abide by duty from duty, and this fact about our moral experience rules out Schiller's idea that the fulfillment of moral laws "also has a certain charm (grace) about it" (V 27:490).

Yet, while Kant reminds us that the moral law issues its commands without attracting us, he denies that law demands our "respect in the manner of painful or despotic commands" (V 27:490). The feeling of respect the moral law elicits in us is akin to a feeling of awe and sublimity

suggests that this puts him in full agreement with Schiller on matters of principle. Schiller's contention is not that grace accompanies virtue, but that grace is at least partially constitutive of virtue. It is therefore not enough for Kant to agree that the virtuous person has a "heart joyous in the compliance of duty," because Schiller's point is that pleasure engages moral action in the genuinely virtuous person and that virtuous person is inclined to do her duty, which she does not experience as an obligation (RGV 6:23n.). Thus, in spite of Kant's conciliatory tone in his official reply to Schiller, there are substantive points of disagreement between them, which Vigilantius helps clarify. 
in response to the unconditional dignity tied up with our own selflegislating rational nature. For Kant, then, pleasure factors into our experience of virtue, but the uniquely moral pleasure associated with virtue is always consequential upon doing one's duty from duty (V 27:490).

In sum, Kant rejects Schiller's conception of the beautiful soul as an appropriate model of moral perfection for finite rational beings because what defines our status as imperfect beings is that we have sensible needs and inclinations that do not of themselves accord with the moral law. More precisely, we have a tendency to grant priority to sensible needs and inclinations that run contrary to duty because of our propensity for evil. ${ }^{23}$ As a result, the best that we can attain is virtue, a morally good disposition to do one's duty from duty and to compel oneself to act in accordance with the moral law from respect, out of necessitation by practical reason.

\section{Conclusion}

As this analysis of Kant's account of virtue in the Lectures on Ethics has shown, Kant thinks of virtue as a form of moral self-mastery or selfcommand that represents a model of self-governance he compares to an autocracy. In light of the fact that the very concept of virtue presupposes struggle and conflict, Kant insists that virtue is distinct from holiness and that any ideal of moral perfection that overlooks the fact that morality is always difficult for us fails to provide an appropriate model of human virtue. No matter how morally good we are or become, virtue remains a disposition to do one's duty from duty, out of necessitation by practical reason. Yet, even though finite rational beings require a power of self-constraint in accordance with the commands of duty to comply with the law (which we obey reluctantly), the virtuous agent displays a unified soul that is at peace. This picture of virtue uncovered from the Lectures on Ethics thus reveals the way in which Kant's conception of virtue accords with his foundational commitments in his moral theory, while at the same time representing a more complex theory of moral character and a life lived in accordance with practical reason.

${ }^{23}$ Schiller realizes that Kant's view that we have "radical tendency" (radikalen Hang) to act in opposition to the moral law supports the idea that moral laws always take the imperatival form for even the person with full virtue, but Schiller rejects this doctrine of evil and is consequently not worried about the risk involved in allowing moralized inclination to execute morally good conduct (GD I72; 208). 